\title{
Has the Implementation of Learning Management System Facilitated Faculty Pedagogy Change?
}

\author{
Hannah Ayaba Tanye \\ Information Technology Studies \\ Department \\ University of Professional \\ Studies, Accra \\ Box LG 149, Accra- Ghana
}

\author{
Albert Akanlisikum Akanferi \\ Information Technology Studies \\ Department \\ University of Professional \\ Studies, Accra \\ Box LG 149, Accra- Ghana
}

\author{
Isaac Asampana \\ Information Technology Studies \\ Department \\ University of Professional \\ Studies, Accra \\ Box LG 149, Accra- Ghana
}

\begin{abstract}
Various research in literature on pedagogical change focused on the effect of professional development programs on pedagogical change. These researches focused on faculty resistance to change and teaching practice by faculty in the classrooms. Some universities in Ghana, have deployed Learning Management Systems (LMS) to aid in the pedagogy change. These universities have deployed various ways to get faculty to use the system but these have had little effect. The current research will focus on whether faculty is comfortable with technology provided to enable them change their pedagogy. The research will also look at their current pedagogical practices. The research will focus on higher educational institutions in Ghana using the University of Professional Studies as a case study. The research seeks to answer the question, "has the implementation of learning management system facilitated faculty pedagogy change?" The study used a quantitative method, specifically a survey was done with a sample of 98 faculty members from the University of Professional Studies, Accra. The study found that majority agreed that the Moodle features is averagely helpful to them, and also that the features of the systems has helped them in their teaching.
\end{abstract}

\section{Keywords}

pedagogy, Moodle, learning management system, teaching, university, theories

\section{INTRODUCTION}

Pedagogy is mostly associated with teaching. Pedagogy is the area that is concerned with the practice and theory of teaching. Teaching strategies as well as facilitator's judgment and decisions, learning theories, meeting student needs, and background of individual students are all informed by the pedagogy adopted by the institution. Pedagogy needs to be explored through the thinking and practice of educators who seek to accompany learners, care for and about them, and bring learning to life (Smith, 2018). Pedagogy is defined by the oxford dictionary as "the method and practice of teaching, especially as an academic subject or theoretical concept." Pedagogy is also defined by the encyclopedia as the art or science of teaching children.

The main activity of universities is to teach and do research to come out with findings to affect and change the way things are done. University teaching has evolved over the years with the advent of the internet. Most schools are blending the conventional face-to-face teaching with elearning. Some universities even do flip learning and some have adopted online learning. It has been established that, techniques used for the conventional face-to-face are not very effective in the blended, online, and flip learning situations (Henderson, 2008). Therefore universities that adopt blended or online teaching should motivate their lecturers to adapt to teaching techniques that would enhance student learning in this environment. Most universities have deployed LMS to aid the conventional classroom teaching. Some have difficulties in whipping the interest of lecturers to adopt a blended learning approach (Blin \& Munro, 2008).

Notwithstanding the resistance, some universities have tried to make it a requirement for faculty members to use the LMS and failure to use it will incur punitive measures. Other universities also require the use of the LMS as a requirement for the confirmation of newly appointed faculty members. All these measures were geared towards whipping the interest of faculty members to change their teaching techniques. These measures have yielded little to no effect (upsa, n.d).

These pedagogical issues also prevail in Ghana. Okudzeto (2016) in an article title Re-thinking and re-defining quality education in Ghana, was of the view that pedagogy has not changed in the country's educational system. Project based learning must be implemented and students should be allowed to work in groups. Thus, there is need for training and support to implement such teaching methods. The draft Inclusive Educational Policy for Ghana advocates for the universal design for learning. This is a learning strategy that advocates for satisfying individual student need. There has been little to no effect in the effort to get faculty to change their pedagogy. Some universities have deployed LMS but there is little usage of the LMS by faculty members (Blin \& Munro, 2008). Agbenyega \& Deku, (2011) in their research, "Building New Identities in Teacher preparation for Inclusive Education in Ghana" found out that, current pedagogical practices are perspective, mechanistic, and do not value student diversity and different learning styles. This research intends to discover the barriers (factors?) to this resistance to change in teaching techniques by most faculty members in the universities as well as the resistance to use learning management systems to serve as a supplementary to the face-to-face teaching. 


\section{PROBLEM STATEMENT}

Globalization has led to massive changes in the way education is delivered to students. Students can now learn in various ways apart from the face-to-face meeting with facilitators. There is now a new breed of students who have access to technology which they use on daily basis. They are open to learn from various ways with the use of technology. This is very important as some students opt for distance learning due to their life style. Most of the students who opt for distance learning are workers, who work to support their schooling (O'Hare, 2012).

With this changing trend in student behavior, facilitators need to adapt a teaching technique that would best impact knowledge to these students. Though a great deal of effort has been put in place to encourage facilitators to use LMS deployed by schools to supplement the face-to-face teaching, the impact is not encouraging.

Although efforts have been put to improve teaching, the impact is not well known (Dancy \& Henderson, 2008). Universities have instituted many policies to ensure the improvement of teaching practices but have not realized the impact of these measures put in place. Research has indentified effective instructional practices for improving learning in university course, but these practices are not widely implemented (Henderson, Finkelstein, \& Beach, 2010).

With the changing trend, there is need for faculty involvement to have an effective teaching technique. Instructional ideas can be disseminated to faculty but there is the need for faculty involvement in the change process, as well as on the environment and structures within which faculty work (Henderson, Finkelstein, \& Beach 2010). Some institutions organize workshops for faculty to help them improve their teaching and focus on student centered approach to teaching. These efforts have not yielded much result as what is said is not what is being done (Ebert-May et al., 2011)

From the afore, this research seeks to unearth the barriers leading to why faculty seem not to be ready to adopt and implement improved teaching techniques in their impacting of knowledge to students by the use of learning management systems deployed by the universities.

\section{OBJECTIVES}

The objectives of the study are:

1. To determine how faculty rate the navigation, search, communication, and help features of the Moodle LMS.

2. To Examine how the Moodle as an LMS facilitate pedagogy change

\section{RESEARCH QUESTIONS}

The Research questions of the study are:

1. What are faculty ratings of Moodle's navigation, search, communication, and help features?

2. To what extend does Moodle aid in faculty pedagogy change?

\section{SIGNIFICANCE OF THE STUDY}

The University of Professional Studies is considering running distance learning programmes(DLS, nd). Usually the teaching methods are part face-to-face and part using LMS. The teaching methods must change to enable the distance learning students construct their own learning through their experience. Distance learning students have lesser hours to meet faculty and as such the LMS will be of great help to faculty to supplement their teaching. The study will enhance faculty decision to use Moodle as an aid to their pedagogy change to be able to satisfy the distance learning students. The study will also be of help to the method of teaching to regular students as well.

In recent years, enrollment into tertiary education has been on the increase. Most applicants who apply for admission into into tertiary institutions are not offered places due to limited vacancies as a result of mainly physical infrastructure. These tertiary institutions are under pressure because their infrastructure cannot support the increasing number of students they enroll. For instance, in 2017, the University of Ghana received a total of 48,728 applications but could only admit 27,239 , that is only $56 \%$ were admitted (https://www.ug.edu.gh/news/university-ghana-holds-2017-

matriculation). Likewise in 2018 , the university received a total of 51,321 applications but offered places to only 30,611 making up approximately $60 \%$ admitted rate (https://www.ug.edu.gh/news/universtiy-ghana-holds-2018-

matriculation). In order to overcome this limitation, tertiary institutions must adopt distance learning to enable them increase intake and reduce pressure on existing infrastructure (Chawinga \& Zozie, 2016). It is also a fact that the cost of tertiary education is on the rise in recent years. Over the years in Ghana both recurrent and capital expenditure on education is on the rise. Specifically, expenditure by government in 2017 was Ghe 8.33 billion and in 2018 increased to Ghe 9.26 billion. This situation can be helped if tertiary institutions should adopt distance learning which is also known to reduce cost of education (SEND Ghana , 2017).

\section{LITERATURE REVIEW}

Pedagogy and Associated Theories

There are a number of theories underpinning the various pedagogical practices. Behaviorism, constructivism, social constructivism, and critical theory. Behaviorism is a learning theory that emphasizes objectively observable behaviors and discounts any independent cognitive activities. Learning according to behaviorist is the acquisition of new behavior based on environmental conditions. Behaviorism which was led by John Watson emerged in the 1910s. Constructivism school of thought especially Piaget (1896-1980) is of the view that knowledge is constructed from experience (PiattelliPalmarini,1980). Constructivism teaching is based on constructivist learning theory. It is based on the belief that learning occurs as learners are actively involved in a process of meaning and knowledge construction as opposed to passively receiving information. Social constructivism by Vygotsky (1986) is of the view that knowledge is constructed through the interactions with others (Vygotsky, 1986).. Critical theory which was first defined by Horkheimer (1937), as a social theory that focuses on critiquing and changing society as a whole (Berendzen, 2009). 
The pedagogy stance for the various learning theory differs. With behaviorism, the pedagogical stance is that there is teacher centered learning which is a performance or visible pedagogy. Usually in the developing countries the concentration is on lecturing, demonstration, direct/ explicit instruction, rote learning and choral repetition. The constructivism stress on student-centered learning which is competence or invisible pedagogy. Usually it is an activity-based learning. The social constructivism is teacher-guided, learner-centered learning. Learning is done in small groups, pair and whole class interactive work. There is also extended dialogue with individuals and higher order questioning. The critical theory has a critical pedagogy.

The adoption of LMS and other technological devices is pushing teaching towards a student centered and how faculty is involving students actively in class. The research is therefore based on constructivism theory of learning to find out how lecturers are leaning towards a constructivist teaching as opposed to the faceface conventional classroom teaching.

\section{RELATED WORK}

According to a research conducted by Henderson, Finkelstein, \& Beach (2010), institutions must go beyond disseminating specific instructional ideas and practices to individual faculty alone but also put emphasis on faculty involvement. They presented four core main change strategies of which disseminating curriculum and pedagogy is one. They were of the view that student learning can improve when instructors move from the traditional transmission style instruction to more student-centered interactive instruction. They further stated that the more reflective faculty is about their teaching will help them develop conceptions of teaching that are student centered. They were of the view that barriers to reform are not communicated to faculty to help them overcome the barriers.

Henderson and Dancy (2007) were of the view that content, coverage, expectations, lack of instructor time, departmental norms, student resistance, class size and room layout, and time structure can impede an instructor's ability to implement innovative instruction. The factors of time, training, incentive and professional identity have been stated as the factors affecting faculty pedagogy change (Brownell \& Tanner, 2012). It has been proven that much time needs to be invested in preparing an interactive course compared to non-interactive course. Ruiz, Mintzer, and Leipzig (2006) in their research found out that pedagogy is moving towards a competency-based curriculum which emphasizes learning outcomes instead of process involved in education. Learning is moving towards the reduction of actual classroom teaching time and the emphasis on adaptive and collaborative learning.

Ebert-May et al. (2011) conducted a survey to verify how a professional development program for faculty affected their teaching style to a learner-centered approach among other things. They indicated that $89 \%$ of faculty stated that they made changes to their course to more learner-centered approach but contrary to observation indicted that participation in the professional development program did not result in instructional change and that $75 \%$ of faculty use teacher-centered approach to their teaching. Some faculty who have exposure to pedagogy change are not self-motivated enough, they still need external barriers to be addressed to enable them change the pedagogy to learner-centered one (Hou \& Wilder, 2015). D'Avanzo (2013) argue that there is lack of research based models and evidence needed to guide the change. Ebert-May et al. (2015) were of the view that, there is no reliable evidence for teaching practices after professional development, which makes effective models for change very difficult. They based their research on implementation of evidence pedagogy of faculty members after a professional development program. They found out that majority of faculty used learner-centered compared to those who use teacher-centered. It is an established fact that research and professional development are both needed to foster instructor pedagogy change (Henderson, 2008; Pelch \& McConnell, 2016). Furthermore, there is need for faculty to reflect on their teaching to enable them change to a more learner centered-approach (Dunn, 2016).

There has been research and training programs to encourage faculty to change teaching modes from teacher-centered to learner-centered. These efforts have not yield wide spread effect (Henderson, 2008). There seem to be faculty resistance to change (Tagg, 2012). There is evidence of efforts put in place to whip up faculty interest to change teaching pedagogy which has not yielded much impact (Henderson, 2008). From the literature, Henderson, Finkelstein, \& Beach (2010) stated that barriers to reform are not communicated to faculty and furthermore, D'Avanzo (2013) argued that there is lack of research based models and evidence needed to guide the change.

In summary, the extant literature suggests that institutions seeking to implement learner-centered models should do so in total agreement and involvement of faculty who are the implementing agencies of the institutions. The literature also identified factors including faculty training, time, incentives and professional identity as those affecting possible change of pedagogy mode from teacher-centered to learner-centered. There is also a lack of empirical research-based models that will aid practical implementation methods by faculty. These have largely led to failure of faculty to make the shift of pedagogical modes that will affect distance learning in higher institutions.

\section{CURRENT STUDY}

Various research in literature on pedagogical change focused on the effect of professional development programs on pedagogical change. These researches focused on faculty resistance to change and teaching practice by faculty in the classrooms. Some universities in Ghana, have deployed Learning Management systems to aid in the pedagogy change. These universities have deployed various ways to get faculty to use the system but this have had little effect. The current research will focus on whether faculty is comfortable with technology provided to enable them change their pedagogy. The research will also look at their current pedagogical practices. The research will focus on higher educational institutions in Ghana using the University of Professional Studies as the case study. The research seeks to answer the question, "has the implementation of learning management system facilitated faculty pedagogy change?"

\section{METHODOLOGY}

This work is an applied quantitative research. It is a survey to assess the views of faculty of the University of Professional Studies, Accra on pedagogical adoption required to enable a learner-centred mode teaching on LMS such as the Moodle. The research was a survey type with the aim of reaching a large 
number of people. Non-probability sampling specifically, convenience sampling was applied in the study. The sample was selected using Kotrlik and Higgins (2001) sample table and selected from faculty members in the University of Professional Studies, Accra. A link to questionnaire designed in Google form was sent to all faculty members through their email. Ninetyeight (98) faculty members filled and returned their questionnaire out of the total of the two hundred and sixty-nine (269) faculty members. The questionnaire used was adopted from Biblioteca by Documentazione Pedagogica (BDP). It was made up of three sections. Section one was on biographic data. Section two was on assessment of Moodle usability which had 20 questions. Section three was on how Moodle helps in teaching and had 15 questions.

The data so collected was analysed utilizing SPSS software version 20 and presented graphically in tables and figures. Then the data was analysed using descriptive statistics employing the characteristics of measures of central tendencies, frequencies and dispersions. The descriptive analysis of the data now provided the first estimates and summaries arranged in tables and graphs set to answer the research questions and meet the study objectives. Then information about the variability or uncertainty in the data, or unexpected patterns and observations made in the data was described, interpreted and conclusions drawn. The graphical methods were adopted to enable better translation of the numerical facts into more concrete and understandable forms.

\section{DATA ANALYSIS}

The sample of respondents was drawn from all faculty members of the University of Professional studies. The questionnaire was sent via the institutions' corporate electronic mail (email) system by the researcher to the 296 faculty members out of which 98 replies were returned. Four responses were eliminated due to excessive missing data which left 94 valid responses. Tables from 1 to 3 present the profile of the respondents with regard to gender, age and number of years of working experience in the organization. Names of the respondents were not included and all were full-time employees in service with the present institution.

\section{Respondent Profile}

Table 1: Indicating frequency and percentage based on gender

\begin{tabular}{|c|c|c|}
\hline & Frequency & Percent \\
\hline Male & 64 & 68.1 \\
\hline Female & 30 & 31.9 \\
\hline Total & 94 & 100.0 \\
\hline
\end{tabular}

Table 1 above indicates that majority of the respondents (68.1\%) were male, followed by female $(31.9 \%)$ in terms of gender.
Table 2: Indicating frequency and percentage based on age

\begin{tabular}{|c|c|c|}
\hline & Frequency & Percent \\
\hline $20-29$ & 4 & 4.3 \\
\hline $30-39$ & 34 & 36.2 \\
\hline $40-49$ & 44 & 46.8 \\
\hline$>50$ & 12 & 12.8 \\
\hline Total & 94 & 100.0 \\
\hline
\end{tabular}

The above table indicates that most of the respondents were in the age group between $40-49$ years $(46.8 \%)$ followed by the age group of 30-39 years (36.2\%), 50 years and above (12.8\%) and the age group between $20-29$ years $(4.3 \%)$.

Table 3: Indicating the frequency and percentage of total work experience in years

\begin{tabular}{|c|c|c|}
\hline & Frequency & Percent \\
\hline 1-5 years & 24 & 25.5 \\
\hline 6-10 years & 38 & 40.4 \\
\hline 11-15 years & 24 & 25.5 \\
\hline 16-20 years & 4 & 4.3 \\
\hline 21-30 years & 4 & 4.3 \\
\hline Total & 94 & 100.0 \\
\hline
\end{tabular}

Table 3 above indicates that most of the respondents were having a work of between $6-10$ years $(40.4 \%)$, followed by $1-5$ years $(25.5 \%), 11-15$ years $(25.5 \%), 16-20$ years $(4.3 \%), 21-30$ years $(4.3 \%)$.

\section{Descriptive Statistics}

Descriptive statistics describes the normality distribution of the scores of the sample under investigation. The descriptive statistics for the variables examined in this study is presented in this section. Tests of internal consistency (Cronbach's Alpha) to assess the reliability of each of the scales used were conducted. All of the measures included in the questionnaire showed acceptable levels of internal consistency reliability. The results indicate that Cronbach's alpha scores for all individual constructs are in the range of 0.892 to 0.943 . Hence, all were above the recommended level of 0.7 (Field, 2009; Hair, Black, Babin, \& Anderson, 2010; Sekaran, 2003). It could be concluded that at this stage there was no internal consistency problems revealed. The internal reliability for Faculty perception of the ease of Moodle navigation as a whole measured .892, ease of Moodle search facilities measured .923, ease of Moodle communication facilities measured .920 , ease of Moodle help facilities measured .910 and to facilitate pedagogy change was .943 for the present sample. 
To map faculty perception towards the Navigation of Moodle facilities in tertiary institutions

Table 4: Indicating mean, standard deviation and normal distribution histogram for Navigational facilities dimensions along with the scale statistics

Descriptive Statistics

\begin{tabular}{|c|c|c|c|}
\hline & $\mathrm{N}$ & Mean & $\begin{array}{c}\text { Std. } \\
\text { Deviation }\end{array}$ \\
\hline Purposeful Page Labelling & 88 & 3.48 & .844 \\
\hline Purposeful Link Labelling & 86 & 3.42 & .926 \\
\hline $\begin{array}{c}\text { Sufficient Navigation Tools } \\
\begin{array}{c}\text { Tnderstandable Navigation } \\
\text { Tools }\end{array}\end{array}$ & 84 & 3.40 & .958 \\
\hline Easy page Navigation & 88 & 3.15 & 1.045 \\
\hline Easy Link Navigation & 88 & 3.11 & 1.033 \\
\hline Efficient page loading & 90 & 3.09 & 1.098 \\
\hline
\end{tabular}

Amongst the seven items making up the scale for Moodle's navigational facilities, faculty perceived purposeful page labelling, purposeful link labelling, sufficient navigation tools and understandable navigation tools were found to have the highest mean ratings (above 3.30). On the other hand, easy page navigation, easy link navigation and efficient page loading received the lowest ratings (below 3.20) on a 5-point Likert scale.

Faculty perceived lowest ease of use of navigational facilities with respect to efficient page loading (3.09) and easy link navigation (3.11) on the scale from very poor (1) to average (3); moderate ease of use of navigational facilities such as easy page navigation (3.15). While ease of use of navigation facilities such as understandable navigation tools (3.32) and sufficient navigation tools (3.40) was perceived to be moderately easier. Highest in ratings was purposeful link labelling (3.42) and purposeful page labelling (3.48).

The perception level of faculty of the ease of navigational facilities of Moodle does not much and in the range 3.00-4.00, peaking close to $3.40-3.50$. The mean value was 3.28 , with standard deviation of .99 and the overall perception of the ease of use of navigational facilities of Moodle was found to be average.

To map perception of faculty towards Search Facilities in Moodle in tertiary institutions

Table 5: Indicating mean, standard deviation and normal distribution histogram for Search facilities on Moodle dimensions along with the scale statistics

\begin{tabular}{|c|c|c|c|}
\hline \multicolumn{4}{|c|}{ Descriptive Statistics } \\
\hline & $\mathrm{N}$ & Mean & Std. Deviation \\
\hline Search Tools Locate Information & 86 & 3.47 & .929 \\
\hline Search Tools Understandable & 86 & 3.33 & 1.011 \\
\hline Search Tools Cover Information & 83 & 3.12 & .942 \\
\hline
\end{tabular}

There are three items comprising the scale for search facilities on Moodle including search tools cover information with the lowest mean ratings (3.12), followed by Search tools understandable (3.33), and the highest being Search tools locate information (3.47).

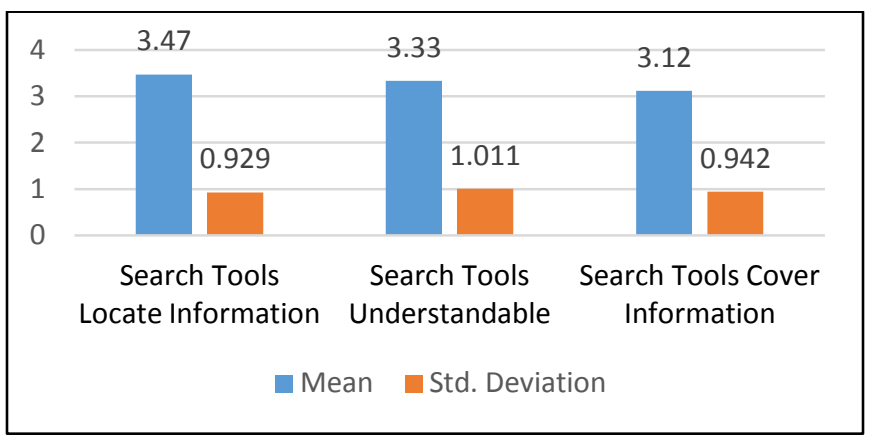

Figure 1.2 Search

The level of perception of search facilities on Moodle did not vary much in the range $2-4$, with a peak close to $3.00-3.50$. The mean value was 3.31, with a standard deviation .961 and the overall perception of the usefulness of the search facilities was found to be average.

To map perception of faculty towards Communication facilities on Moodle in tertiary institutions

Table 6: Indicating mean, standard deviation and normal distribution histogram for Communication facilities dimensions along with the scale statistics

Descriptive Statistics

\begin{tabular}{|c|c|c|c|}
\hline & $\mathrm{N}$ & Mean & $\begin{array}{c}\text { Std. } \\
\text { Deviatio } \\
\mathrm{n}\end{array}$ \\
\hline Easy to understand messages & 88 & 3.30 & .730 \\
\hline Easy to use communication tools & 86 & 3.26 & .884 \\
\hline Effective communication tools & 86 & 3.15 & .964 \\
\hline Easy to use interactive features & 84 & 3.02 & .969 \\
\hline Effective interactive features & 84 & 3.00 & .982 \\
\hline
\end{tabular}

Of the five items comprising the communication facilities, faculty perceived all the items to be of average mean ratings. The lowest mean rating was on the item effective interactive features (3.00) and the highest was easy to understand messages (3.30) on a 5-point Likert scale.

Faculty perceived an average ease of use communication facilities with respect to effective interactive features (3.00), easy to use interface features (3.02) on the scale from poor (2) to average (3); moderate ease of communication facilities such as effective communication tools (£.15). The highest rating was on the items easy to understand messages (3.30) and easy to use communication tools (3.26). 


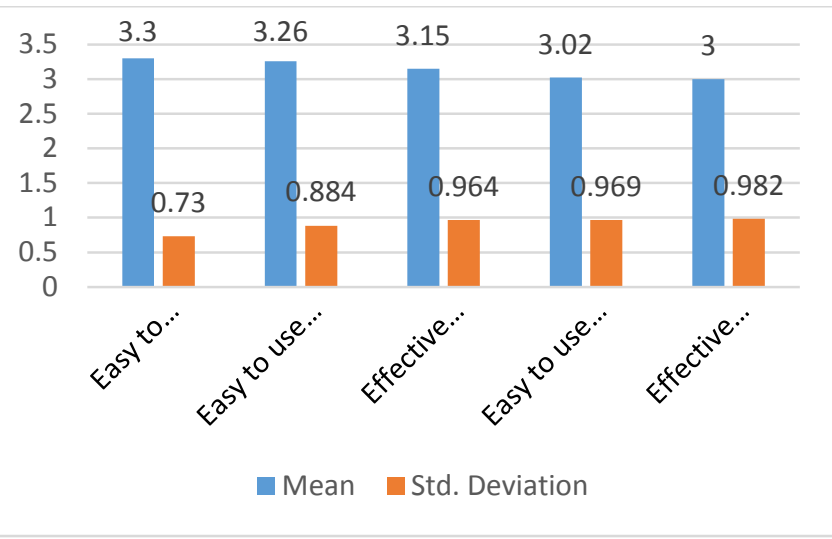

Figure 1.3 Communication

The level of perception of importance of communication facilities does not vary much in the range $3.00-4.00$, with a peak close to $3.00-3.30$. The mean value was 3.15 , with standard deviation .906 . The overall perception of ease of use of communication facilities of Moodle was found to be average.

To map perception of faculty towards Help Facility on Moodle in tertiary institutions

Table 7: Indicating mean, standard deviation and normal distribution histogram for Help facility on Moodle dimensions along with scale statistics.

Descriptive Statistics

\begin{tabular}{|c|c|c|c|}
\hline & $\mathrm{N}$ & Mean & $\begin{array}{c}\text { Std. } \\
\text { Deviation }\end{array}$ \\
\hline Clear instructions for plug-ins & 90 & 3.02 & .912 \\
Essential help for communication & 90 & 3.02 & .936 \\
$\begin{array}{c}\text { Essential Help for navigation and } \\
\text { search }\end{array}$ & 86 & 2.98 & .933 \\
$\begin{array}{c}\text { Essential instructions } \\
\text { Essential help for technical problems }\end{array}$ & 90 & 2.96 & .970 \\
& 90 & 2.71 & .939 \\
\hline
\end{tabular}

Amongst the five items making up the scale for Moodle's help facilities, faculty perceived clear instructions for plug-ins and essential help for communication were found to have the highest mean ratings (just above 3.00). On the other hand, essential help for navigation and search, essential instructions and essential help for technical problems received the lowest ratings (below 3.00) on a 5-point Likert scale.

Faculty perceived as poor of the usefulness of help facilities on Moodle with respect to essential help for technical problems (2.71), essential instructions (2.96) and essential help for navigation and search (2.98) on the scale from very poor (1) to average (3); moderate usefulness of help facilities of Moodle with regards to essential help for communication (3.02) and clear instructions for plug-ins (3.02).

The level of perception of the usefulness of the help facilities on Moodle did not vary much in the range $2-3$, with a peak close to $3.00-3.02$. The mean value was 2.94 , with a standard deviation .938 and the overall perception of the usefulness of the help facilities on Moodle was found to be poor.

To map how Moodle facilitate the move of faculty towards pedagogy change in tertiary institutions.

Table 8: Indicating mean, standard deviation and normal distribution histogram for pedagogy change facilitation dimensions along with scale statistics.

Descriptive Statistics

\begin{tabular}{|c|c|c|c|}
\hline & $\mathrm{N}$ & Mean & $\begin{array}{c}\text { Std. } \\
\text { Deviation }\end{array}$ \\
\hline Publish own Material & 88 & 3.10 & .983 \\
Create own teaching material & 90 & 2.92 & .974 \\
Develop lesson plan and Activities & 90 & 2.83 & 1.084 \\
Develop Tests to Assess Learners & 90 & 2.78 & .921 \\
Collect Information & 94 & 2.73 & .941 \\
Choose among Alternatives & 94 & 2.70 & .926 \\
Set own Objectives & 94 & 2.69 & .928 \\
Search for Information & 92 & 2.68 & 1.026 \\
Design and Develop Projects & 90 & 2.62 & 1.097 \\
Communicate with Learners & 88 & 2.56 & .945 \\
Collaborate with Colleagues & 86 & 2.52 & .930 \\
Share Experience with Colleagues & 88 & 2.51 & .897 \\
Use Evaluative to Assess & 87 & 2.46 & .775 \\
Professional help available & 88 & 2.39 & 1.055 \\
Technical and Pedagogical & 88 & 2.20 & .984 \\
Support & & & \\
\hline
\end{tabular}

Amongst the fifteen items making up the scale for Moodle's facilitation for pedagogy change, faculty perceived publish own material is found to have the highest mean ratings (above 3.00). Dimensions such as use evaluative to assess, professional help available and technical and pedagogical support received the lowest ratings (below 2.50) on a 5-point Likert scale.

Faculty perceived as poor the use of Moodle to facilitate pedagogy change in tertiary institutions with respect to create own teaching material (2.92), develop lesson plan and activities ((2.83), develop tests to assess learners ((2.78), collect information (2.73), choose among alternatives (2.70), set own objectives (2.69), search for information (2.68), design and develop projects (2.62), communicate with learners (2.56), collaborate with colleagues (2.52), share experience with colleagues (2.51), use evaluative to assess (2.46), professional help available (2.39) and Technical and pedagogical support (2.20) on the scale from very poor (1) to average (3). Faculty perceived as average the use of Moodle to facilitate pedagogy change in tertiary institution with regards to publish own material (3.10).

Figure 1.5 Pedagogy Change 
The level of perception of the usefulness of Moodle to facilitate pedagogy change in tertiary institutions did not vary much in the range $2-3$, peaking close to $2.90-3.10$. The mean value was 2.65, with a standard deviation .966 and the overall perception of the usefulness of Moodle to facilitate pedagogy change in tertiary institution was found to be poor.

\section{DISCUSSION}

Moodle is an open-source learning management system and among the seven best learning management system, and also SCROM compliant (Handrick, 2018). SCORM is Shareable Content Object Reference Model is a collection of standards and specifications for web-based electronic educational technology (also called e-learning). SCORM also defines how content may be packaged into a transferable ZIP file called "Package Interchange Format." Many researches have concluded that Moodle is one of the best learning management system one can use to enable faculty pedagogy change (Psycharis, Chalatzoglidis \& Kalogiannakis, 2013).

The respondents' responses to Moodle usability was varied. The majority of the respondents responded averagely to Moodle navigation. $38.3 \%$ stated that the pages are loaded quickly and efficiently is average. Though $8.5 \%$ stated that the it is very poor. More so $29.8 \%$ stated that it is good. From the analysis, $19.1 \%$ find it difficult with the pages loaded on Moodle. Most of the respondents $33 \%$ stated that navigation from page to page is easy, $24.5 \%$ stated that it is good, and a significant number that is $8.5 \%$ stated that it is very poor. Most of the respondents about $38.3 \%$ stated that the Links are clearly labelled and serve an easily identified purpose is good, though $14.9 \%$ stated that it was poor. As to whether the navigation tools provided are easy to understand and use, $10.6 \%$ stated it is poor whiles $5.3 \%$ stated it is very poor. Though $29.8 \%$ stated it is good whiles $31.9 \%$ stated it is average.

On the feature of the search facility in Moodle, $46.8 \%$ stated that the search tools provided are easy to understand and use is good or very good, though $17 \%$ stated it is poor or very poor. As to whether the search tools provided "cover" the whole information of the resource, $36.1 \%$ stated it is good or very good, $23.4 \%$ stated that it is poor or very poor. On the feature of communication on Moodle, less than $38.3 \%$ of respondent stated it is good. A significant number of $19.1 \%$ stated it is poor or very poor, and about $30.9 \%$ stated it is average. $38.3 \%$ said the help facility that is essential help is provided for using navigation and search tools is average, $25.5 \%$ stated it is good, and $25.5 \%$ stated it is poor or very poor.

Many researches have concluded that Moodle is one of the best learning management system one can use to enable faculty pedagogy change (Psycharis, Chalatzoglidis \& Kalogiannakis, 2013). From the findings, majority of the respondents said it is average and less than $50 \%$ actually stated that the features of Moodle is good. A significant number about $24 \%$ stated the features are poor or very poor.

From the research findings, most of the respondents agree that the features in Moodle is just average. How does it then affect their pedagogy? As to how Moodle help the teachers to teach. Most faculty members, about $46.4 \%$ stated that they are able to set their learning objectives when using Moodle is average $41.5 \%$ stated little or not at all. This is a significant number which goes to show that objectives which is the most important aspect of teaching cannot be set little or not at all in Moodle by this significant number of faculty members. As to whether faculty can create their own teaching and learning material, almost half of the respondents, that is $43.6 \%$ stated average, $26.6 \%$ stated much and $12.8 \%$ stated little. $45.7 \%$ of the respondents stated they can develop lesson plans and classroom activities in Moodle is average, $28.7 \%$ stated not at all or little. This is a significant number, and $20.3 \%$ stated much or very much. $47.9 \%$ stated that the features of Moodle is average in using it to share opinions and experiences in using the resource with colleagues and ask for and receive professional support from subject area experts. 17\% stated not at all, and 20.2 stated little. As to whether faculty is able to set test on Moodle to assess students, $42.6 \%$ stated average, $21.3 \%$ stated little, $10.6 \%$ stated not at all, and $21.3 \%$ stated much.

Respondents stated that the usability of Moodle in respect to the navigation, search facility, communication, and help facilities in Moodle features is average. This reflected in whether it has affected their teaching. It was found out that it is also average. This implies that good Moodle features will positively aid faculty pedagogy change.

\section{CONCLUSION}

Moodle is an open-source learning management system and among the seven best learning management system, and also SCROM compliant (Handrick, 2018). SCORM is Shareable Content Object Reference Model is a collection of standards and specifications for web-based electronic educational technology (also called e-learning). SCORM also defines how content may be packaged into a transferable ZIP file called "Package Interchange Format." Many researches have concluded that Moodle is one of the best learning management system one can use to enable faculty pedagogy change (Psycharis, Chalatzoglidis \& Kalogiannakis, 2013).

Though teachers have positive perception of moodle the effect on their teaching is not being experience by a majority of them (Sallam, \& Alzouebi, 2014). This is a contradiction. For instance the majority of respondents stated that it only average affect their teaching averagely and just a few stated their teaching has been affected much.

According to Singh (2017) the twelve reasons why anyone should choose Moodle are: it is truly open source, it has sound educational philosophy, proven and trusted worldwide, designed to support both teaching and learning, easy to use, always up-todate, community support, great documentation and forum support, highly flexible and fully customizable, language options, international standard compliant, and interoperability. Moodle by far has been tested and found out to be very supportive of teaching activities because of its strong educational philosophy.

By far and large, Moodle has been accepted and it has been tested and proven to be on of the best seven learning management system (Psycharis, Chalatzoglidis \& Kalogiannakis, 2013). However, from the findings of the research, most faculty members stated that the features of Moodle usability in the areas of navigation, search, communication and help is average and this reflected in whether it affected their teaching. Most of faculty will better appreciate Moodle features if there is hands-on training geared towards getting familiar with the Moodle platform. Lack of training can 
affect the way faculty view the Moodle platform and subsequently affect their output and there would less impact on pedagogy (Martinelli, 2018)

\section{REFERENCES}

[1] Berendzen, J. C. (2009). Max Horkheimer

[2] Blin, F., \& Munro, M. (2008). Why hasn't technology disrupted academics' teaching practices? Understanding resistance to change through the lens of activity theory. Computers \& Education, 50(2), 475-490.

[3] Brownell, S. E., \& Tanner, K. D. (2012). Barriers to faculty pedagogical change: Lack of training, time, incentives, and... tensions with professional identity? CBE-Life Sciences Education, 11(4), 339-346.

[4] Chawinga, W. D., \& Zozie, P. A. (2016). Increasing access to higher education through open and

[5] disstance learning: Empirical findings from Mzuzu University, Malawi. The International

[6] Review of Research in Open and Distributed Learning, 17(4).

[7] D'Avanzo, C. (2013). Post-vision and change: do we know how to change? CBE-Life Sciences Education, 12(3), 373 382.

[8] Dancy, M., \& Henderson, C. (2008). Barriers and promises in STEM reform. In Henderson, Beach \& Finkelstein (Eds.), In National Academies of Science Promising Practices Workshop.

[9] Dunn, L. (2016). Teaching and digital technologies: big issues and critical questions, edited by

[10] M. Henderson, and G. Romeo. Curriculum Journal, 27(4), 560-561.

[11] Ebert-May, D., Derting, T. L., Henkel, T. P., Maher, J. M., Momsen, J. L., Arnold, B., \& Passmore, H. A. (2015). Breaking the cycle: Future faculty begin teaching with learner-centered strategies after professional development. CBE-Life Sciences Education, 14(2).

[12] Ebert-May, D., Derting, T. L., Hodder, J., Momsen, J. L., Long, T. M., \& Jardeleza, S. E. (2011). What we say is not what we do: effective evaluation of faculty professional development programs. BioScience, 61(7), 550-558.

[13] Field, A. (2009). Discovering statistics using SPSS (3rd ed.). London: SAGE Publications Ltd.

[14] Hair, J. F., Black, W. C., Babin, B. J., \& Anderson, R. E. (2010). Multivariate Data Analysis: A Global Prespective (7th ed.). New Jersey: Pearson Education.

[15] Henderson, C. (2008). Promoting instructional change in new faculty: An evaluation of the physics and astronomy new faculty workshop. American Journal of Physics, 76(2), 179-187.

[16] Henderson, C., \& Dancy, M. H. (2007). Barriers to the use of research-based instructional strategies: The influence of both individual and situational characteristics. Physical Review Special Topics-Physics Education Research, 3(2), 020-102.

[17] Henderson, C., Finkelstein, N., \& Beach, A. (2010). Beyond dissemination in college science teaching: An introduction to four core change strategies. Journal of College Science Teaching, 39(5), 18.

[18] Hou, S. I., \& Wilder, S. (2015). Changing Pedagogy: Faculty Adoption of Service-Learning: Motivations, Barriers, and Strategies Among Service-Learning Faculty at a Public Research Institution. SAGE Open,, 5(1).

[19] Kotrlik, J. W. K. J. W., \& Higgins, C. C. H. C. C. (2001). Organizational research: Determining appropriate sample size in survey research appropriate sample size in survey research. Information technology, learning, and performance journal, 19(1), 43.

[20] O'Hare, S. (2012). Why distance learning worked for me Retrieved January 3, 2019, from https://jobs.telegraph.co.uk/article/case-studies-whydistance-learning-worked-for-me/

[21] Pelch, M. A., \& McConnell, D. A. (2016). Challenging instructors to change: A mixed methods investigation on the effects of material development on the pedagogical beliefs of geoscience instructors. International Journal of STEM Education, 3(1), 5.

[22] Ruiz, J. G., Mintzer, M. J., \& Leipzig, R. M. (2006). The impact of e-learning in medical education. Academic medicine, 81(3), 207-212.

[23] Sekaran, U. (2003). Research Methods for Business: A Skill-Building Approach (4th ed.): John Wiley \& Sons. Inc.

[24] SEND Ghana (2017) 2018 budget: SEND Ghana's assessment points out 'serious concerns'

[25] https://www.myjoyonline.com/news/2017/november17th/2018-budget-send-ghanas - assessmentpoints-out-serious-concerns.php

[26] Piattelli-Palmarini, Massimo (ed.) (1980). Language and Learning: The Debate Between Jean

[27] Piaget and Noam Chomsky_. Harvard University Press.

[28] Tagg, J. (2012). Why does the faculty resist change? Change:. The Magazine of Higher Learning, 44(1), 6-15.

[29] Vygotsky, L. S. (1986). Thought and language. Cambridge, MA: MIT Press 